\title{
Obituary
}

\section{Prof. O. V. DARbishire}

$\mathrm{B}^{\mathrm{o}}$ ORN at Conway in 1870, Otto Vernon Darbishire had the advantage of a varied education, passing his school years in Dresden and Florence and pursuing his university studies at Bangor, Oxford and Kiel. Thus he gained not only a wide outlook on life, but became also a good linguist-an inestimable advantage for a scientific worker. After graduating with honours in botany at Oxford, where he studied under Prof. Vines, he went to Kiel, and there took up first the study of Algæ, obtaining the Ph.D. degree. He then became assistant to Prof. Reinke and commenced his investigations into the structure and development of lichens, a study which he pursued throughout his life. He also turned his attention to the taxonomy of this group of plants, publishing an important monograph of the genus Roccella in the "Bibliotheca botanica" in 1899. By his researches and publications on lichens be became one of the leading authorities on this group of plants, and was entrusted with the determination of the lichens collected by the second Norwegian expedition of the Fram and also of those collected by the Swedish Antarctic expedition.

In 1898, Darbishire was appointed lecturer in botany in the University of Manchester, a post which he held until 1909 when he was appointed lecturer in the Armstrong College, Newcastle-on-Tyne. In 1911 he went to the University of Bristol, first as lecturer and head of the Department of Botany and afterwards in 1919 as the first holder of the newly established Melville Wills chair of botany. His duties in Manchester necessitated his specialising to some extent in plant physiology, and his wide interests led him to take an active part in the work of the Central Committee for the Survey and Study of British Vegetation, which afterwards developed into the British Ecological Society. Nevertheless, though his time was during the later part of his career fully occupied with heavy teaching and organising duties, he never lost his interest in lichens and even during the past few years he published several important contributions to lichenology in the Annals of Botany, in Flora and in the Annales de Cryptogamie exotique.

Darbishire was a good teacher and took an active personal interest in his students. While in Manchester, he undertook voluntarily for some years the instruction in botany of a class of small children, and the outcome of the experience so gained was the publication of a "Plant Book for Schools". He was equally successful with university students, and the botanical department at Bristol owes much to the energy with which he developed the botanical teaching in the University during the twenty-three years of his association with it. He took an active interest in other aspects of the students' life, acting as commanding officer of the Officers Training Corps during the War and for two years afterwards. Outside the University he interested himself in the work of the
Bristol Naturalists' Society and in that of the South Western Naturalists' Union, of which he was the president.

A few years ago, Darbishire met with a serious cycling accident, which incapacitated him almost completely for some considerable time. Happily his recovery, though slow, was sure, and he completely regained his powers, so that he could again undertake both his teaching and his research work. He was no doubt looking forward to the opportunity after his retirement, which was due next year, to devote more time to the investigation of lichens, and we might have expected further important contributions to botanical science. But alas, it was not to be. Taken ill very suddenly, he died after an operation on October 11 at the age of sixty-four years, leaving a widow and two young sons.

$$
\text { F. E. W. }
$$

\section{Miss E. A. WillmotT}

IT is with great regret that we have to record the sudden passing of Ellen Willmott at Warley Place, Brentwood, on September 27 last, at the age of seventy-four years.

Scientific gardeners are rare in any age, and the good work accomplished by Ellen Willmott in scientific horticulture during her long life will be remembered and appreciated for centuries to come. From the scientific point of view, her most enduring work will probably be her magnificent monograph of the genus Rosa, to which she devoted the best years of her life and a considerable part of her private fortune. In many ways this monograph de luxe is unique, and nothing approaching it had appeared for nearly a century. It was in 1817 that Redouté first produced his beautiful folio plates of "Les Roses", but even that treasure pales in artistic and scientific significance before the accurate and life-like illustrations of Willmott's "Rosa". Such fidelity to Nature in a botanical work is extremely rare, and considerably increases its scientific value. In Alfred Parsons, Willmott discovered a scientific artist, and the careful reproduction of his drawings reflects the utmost credit on all concerned. Baker, who was responsible for the Latin diagnoses and bibliography, was a distinguished botanist who had made a special study of roses. The charming literary. historical and horticultural notes on each species were contributed by Willmott herself and were the result of many years' research and horticultural experience.

It is evident that the whole conception of the work, and the welding together of the artistic and scientific elements into a realistic whole with a universal appeal, were due entirely to the genius of Ellen Willmott, and her monograph on roses stands as a lasting monument to her artistic and scientific: sensibilities.

\section{C. Hurst.}

